\title{
Analisis Implementasi Keteladanan Dai dalam Efektivitas Dakwah di Era Kontemporer
}

\author{
Oleh : Faridah ${ }^{1}$
}

Jurusan Bimbingan Konseling Islam

STAIM Sinjai

Abstrak : penelitian ini membahas tentang analisis implementasi keteladanan dai dalam efektivitas dakwah di era kontemporer. Studi ini dilakukan dalam rangka menjawab problematika dakwah tentang keteladanan dai. Penelitian ini merupakan penelitian yang bersifat deskriptif kualitatif yang memberikan gambaran mendalam tentang gejala-gejala sosial tertentu atau aspek sosial tertentu masyarakat yang diteliti. Keteladanan dai merupakan salah satu metode dakwah yang dikenal dengan dakwah bi al-Khal atau dakwah dengan tindakan yakni dengan memberika contoh tentang hal yang didakwahkan. Kehidupan di era kontemporer dengan permaslahan yang kompleks menjadi suatu problematika dakwah yang membutuhkan pembenahan dalam aktivitas dakwah terutama akibat krisis keteladanan dai yang melanda sehingga masyarakat banyak yang beriskap apatis terhadap dakwah Islam. Kesadaran tentang pentingnya keteladanan dai dalam aktivitas dakwah akan berdampak pada efektivitas dakwah. Karena baik sikap, ucapan dan tindakan dai mampu menjadi inspirasi dan motivasi pada mad'u untuk mempelajari serta mengamalkan pesan dakwah yang diterima.

Keywords : Keteladanan, dai, Efektivitas Dakwah, dakwah kontemporer.

\section{Pendahuluan}

Fenomena kehidupan masyarakat kontemporer menghadirkan kehidupan yang serba instan, menyuguhkan kemudahan beriringan dengan permasalahan yang ditimbulkan. Proses modernisasi, kehidupan yang mengalami kegoncangan baik psikologis maupun social culture serta adanya tekanan kebutuhan yang semakin meningkat. Kehidupan kontemporer adalah kehidupan yang menyuguhkan ragam dinamika hidup. Hal ini menimbulkan keluhan psikologis, gejala keresahan batin yang mengarah pada gejala gangguan jiwa (neurosa) ${ }^{2}$.

\footnotetext{
${ }^{1}$ Dosen STAI Muhammadiyah Sinjai

${ }^{2}$ Totok Jumantoro, Psikologi Dakwah dengan Aspek-Aspek Kejiwaan yang Qur'ani (Cet.1; Amzah, 2001), h. 2 .
} 
Menganalisis kondisi kehidupan masyarakat kontemporer, seorang dai atau lembaga dakwah perlu memahami persoalan yang dihadapi oleh masyarakat dakwah, memahami karakteristik mad'u agar mampu menentukan langkah yang akan ditempuh dalam upaya memecahkan masalah yang dihadapi. ${ }^{3}$

Dakwah merupakan denyut nadi Islam. ${ }^{4}$ Sehingga tanpa dakwah, Islam akan mengalami kemandekan, stagnan, tidak berkembang dan tidak akan dikenal dikalangan umat manusia. Islam yang senantiasa digaungkan sebagai rahmat untuk semesta alam akan hilang dan lenyap ditelan zaman.

Dakwah merupakan suatu kewajiban yang diperintahkan oleh Tuhan seperti yang tercantum dalam QS. Ali-Imran ayat 104 dan dititahkan oleh Nabi Muhammad saw. بلغو اعنى اية و ${ }^{5}$ Sampaikanlah dari Rasulullah walau hanya satu ayat, suatu kewajiban yang tidak bisa dihindari karena risalah Islam adalah merupakan rahmat bagi semesta alam yang harus dirasakan dan dinikmati oleh seluruh makhluk yang ada di alam ini.

Seiring perkembangan zaman, dakwah juga semakin berkembang dengan ragam corak dan aktivitasnya. Perkembangan dakwah dari masa ke masa cukup dinamis. Suatu harapan besar terhadap dakwah senantiasa bertumbuh dan berkembang. Setelah komunisme runtuh dan terjadi friksi besar dalam peta kekuatan dunia, agama Islam justru semakin diminati oleh seluruh kalangan di dunia. Kenyataan ini merupakan angin segar dalam perkembangan dakwah meskipun butuh kerja keras, kesabaran dan keseriusan. ${ }^{6}$ Berdakwah ibarat penerimaan tongkat estafet yang memerlukan kesinambungan dan usaha yang konsisten serta sistematis.

\footnotetext{
${ }^{3}$ Asep Muhyiddin dan Agus Ahmad Safei, Metode Pengembangan Dakwah (Cet.I; Bandung: Pustaka Setia, 2002), h. 87.

${ }^{4}$ Moh. Ali Aziz, Ilmu Dakwah Edisi Revisi, h. 5.

5, Abu 'ĪSa MuḥAmmad Bin 'ĪSa Bin ȘUrah AttirmidżI, ȘUnan Al-Turmudż, Juz IV (Semarang: Toha Putra, Tt), h. 147.

${ }^{6}$ Wahyu Ilaihi dan Harjani Hefni Polah, Pengantar Sejarah Dakwah (Cet.II; Jakarta: Kencana, 2012), h. 238.
} 
Perjalanan dakwah dari masa ke masa meskipun mengalami perkembangan yang dinamis, namun mengalami ragam rintangan sesuai dengan konteks dan zaman pada saat dakwah dilakukan. Problematika dakwah kontemporer tersebut memerlukan kajian dan analisis akan konsep efektivitas dakwah yang diharapkan terwujud di tengah ragam problematika umat yang semakin kompleks.

Mengamati problematika umat sekarang dengan menganalisis penerimaan dan penerapan akan pesan-pesan dakwah yang disampaikan, dapat dikatakan bahwa efektivitas dakwah yang ditemui belum mencapai tingkat yang diharapkan. Tingkat kejahatan atau kriminalitas baik kualitas maupun kuantitasnya berdasarkan pengamatan baik langsung maupun melalui media komunikasi semakin meningkat.

Peningkatan kejahatan (kriminalitas) otomatis mengisyaratkan degradasi moral yang juga semakin merejalela. Menyikapi hal tersebut, memerlukan kajian dan pemikiran yang mendalam, upaya apa yang dapat ditempuh untuk mengantisipasi krisis moral yang terjadi. Krisis moral yang melanda diharapkan mampu diantisipasi dengan kehadiran dakwah sebagai problem solving dalam kehidupan masyarakat. Terjadinya banyak penyimpangan dalam kehidupan manusia mendorong kehadiran risalah melalui dakwah yang pada hakikatnya untuk mengembalikan manusia kepada mentaati hukum kehidupan yang telah digariskan Tuhan yang dapat mengantarkan manusia kepada kebahagiaan dunia dan akhirat. ${ }^{7}$

Dakwah yang diharapkan sebagai problem solving dalam kehidupan umat mengisyaratkan perlunya pembenahan dalam aktivitas dakwah. Pembenahan dalam dakwah diarahkan untuk mencapai dan mewujudkan efektivitas dakwah. Karena fenomena kehidupan menggambarkan bahwa realitas pertumbuhan dan perkembangan dakwah beriringan dengan kemaksiatan yang semakin merajalela. Problematika dakwah yang seringkali ditemui adalah

${ }^{7}$ M.Anwar Arifin, Dakwah Kontemporer Sebuah Studi Komunikasi (Cet.I; Yogyakarta: Graha Ilmu, 2011), h. 4-5 
sikap apatis masyarakat terhadap dakwah. Keengganan untuk mengamalkan ajaran agama bahkan keengganan untuk mengenal dan mengetahui ajaran agama.

Ragam problematika dakwah seperti sikap apatis umat terhadap dakwah menjadi suatu bahan analisis tentang pembenahan dakwah dan aspek yang melingkupinya, serta harapan dan upaya yang mampu mengantarkan umat memasuki gerbang dakwah, mempelajari, memahami dan mengamalkannya. Karena sungguh suatu keniscayaan untuk mengamalkan pesan dakwah, apabila untuk mengenal dan mengetahuinya saja sudah tidak mau.

Dai merupakan salah satu aspek dakwah yang paling berperan dalam aktivitas dakwah. Menyikapi sikap apatis umat, dai selayaknya menjadi pertama dan utama yang perlu untuk melakukan pembenahan. Keberadaan dai dengan ragam karakteristik yang dimiliki sangat berpengaruh pada penerimaan umat. Ucapan, sikap dan tindakan (perbuatan) dai senantiasa menjadi sorotan dan akan menuai respon dari masyarakat.

\section{Dai dan Karakteristiknya}

Dai (subjek dakwah) adalah setiap orang yang mengajak kepada perubahan yang lebih baik dalam menjalankan nilai Islam. Dai atau subjek dakwah menurut Acep Aripuddin bisa berupa individual, kelompok, organisasi, atau lembaga yang dipanggil untuk melakukan tindakan dakwah. ${ }^{8}$ Hal yang sama juga dinyatakan oleh Arifuddin bahwa dai adalah orang yang melaksanakan dakwah baik lisan maupun tulisan ataupun perbuatan, baik secara individu, kelompok, atau dalam bentuk organisasi atau lembaga. ${ }^{9}$

Keberadaan dai dalam proses dakwah adalah hal yang sangat penting, sehingga dai menduduki posisi sentral dalam dakwah. Karena bagaimana pun baiknya ideologi Islam yang

\footnotetext{
${ }^{8}$ Acep Aripudin, Pengembangan Metode Dakwah; Respons Dai Terhadap Dinamika Kehidupan Beragama di Kaki Ciremai (Ed.1, Jakarta: Rajawali Pers, 2011), h. 3.

${ }^{9}$ Arifuddin, Metode Dakwah Dalam Masyarakat Plural; Suatu Penelitian Kualitatif, (Jakarta: Rabbani Press, 2012), h. 56.
} 
harus disebarkan di masyarakat, ideologi tersebut akan tetap menjadi ide dan tetap sebagai citacita yang tidak terwujud jika tidak ada yang menyebarkannya. ${ }^{10}$

Penyebaran ideologi Islam di masyarakat sebagai ajaran untuk keselamatan dan kemuliaan selayaknya disebarkan atau disampaikan dengan rendah hati, bijaksana, dan penuh santun. Hal ini merupakan tanggung jawab setiap muslim, baik pria maupun wanita. ${ }^{11}$

Tugas dan tanggung jawab menyerukan dan meyebarkan ideologi Islam adalah tugas dai sebagai seorang muslim. Dai dalam setiap aspek kehidupannya terbagi beberapa tipologi yang diuraikan oleh al-Habib 'Abdullah bin 'Alawi al-Haddad seperti dikutip Moh. Ali Aziz, diantaranya:

a. Dai menguasai ilmu agama, perilakunya sesuai dengan ilmunya, dan dai ikhlas mengajarkan dan mengajak orang lain mengikuti ilmunya.

b. Memiliki kedalaman ilmu agama, bersemangat mengajarkan ilmu yang dimiliki tetapi perilaku dai tidak sesuai dengan ilmu yang dimiliki. Keteladanan dianggap tidak penting, ibarat memberikan pakaian ke orang lain sedangkan dirinya dalam keadaan telanjang. ${ }^{12}$

Tipologi dai seperti yang dipaparkan menyiratkan pentingnya pengamalan ilmu yang dimiliki oleh seorang dai, sebab pengabaian tersebut diibaratkan dai berusaha menutup aurat orang lain tetapi auratnya sendiri terbuka.

Pada umumnya umat Islam adalah dai, hal ini tergantung dari tingkat pemahaman dan kemampuan dakwahnya. Karena yang paling utama dalam dakwah adalah keinginan untuk mempelajari ajaran Islam dan mengamalkannya sehingga pelakuknya mampu menjadi contoh atau teladan untuk orang sekitarnya. Umat Islam (muslim) merupakan suatu komunitas yang ditegakkan di atas sendi-sendi moral, Islam dan takwa. Komunitas muslim berdasarkan pada

\footnotetext{
${ }^{10}$ Moh. Ali Aziz, Ilmu Dakwah Edisi Revisi (Jakarta: Kencana, 2009), h. 216.

${ }^{11}$ Djamalul Abidin Ass, Komunikasi dan Bahasa Dakwah ( Jakarta: Gema Insani Press, 1996), h. 8.

${ }^{12}$ Moh. Ali Aziz, Ilmu Dakwah, Edisi Revisi (Cet. II; Jakarta: Kencana, 2009), h. 230-240.
} 
surat al-Baqarah ayat 143 yang dipahami secara utuh dan padu adalah teladan di tengah arus kehidupan yang serba kompleks, penuh dengan dinamika perubahan, tantangan dan pilihan yang terkadang dilematis. ${ }^{13}$

Menghadapi dan menjalani ragam tantangan kehidupan yang juga merupakan tantangan dakwah, seorang dai harus memiliki beberapa kompetensi yang meliputi kekuatan intelektual (knowledge), keterampilan (skill), sikap dan moral (attitude), serta kekuatan spiritual (spiritual power). ${ }^{14}$ Ragam kompetensi tersebut diharapkan mampu menjadikan dai tangguh dalam menjalankan aktivitas dakwah, sehingga mampu membawa umat menuju peradaban Islam dalam mewujudkan rahmat bagi semesta alam. Menurut Acep Aripudin,

Seorang dai yang kredibel adalah seorang yang memiliki kompetensi di bidangnya, integritas kepribadian, ketulusan jiwa dan memiliki status yang cukup. Dai harus menjadi saksi kebenaran menjadi teladan umat dan berakhlak mulia yang mencerminkan nilainilai Islam. ${ }^{15}$

Usaha dan perjuangan untuk menjadi teladan umat tidak mudah. Sejarah membuktikan betapa perjuangan dakwah telah menorehkan luka, kepedihan dan ragam fenomena kehidupan. Berjuang di jalan dakwah berarti siap menerima dan menghadapi ragam respon umat tentang dakwah. Respon yang sesungguhnya lebih banyak membutuhkan kesabaran dan kelapangan hati serta keikhlasan.

Keragaman respon tentang dakwah adalah akibat dari dinamika kehidupan dan ragam tipologi umat yang dihadapi. Mengantisipasi problematika dakwah tersebut, seorang dai mutlak membekali diri dengan ilmu dan akhlak mulia, mengingat bahwa tugas dakwah bukanlah pekerjaan mudah, semudah membalik telapak tangan dan tidak dapat dilakukan oleh sembarang

\footnotetext{
${ }^{13}$ M. Munir dkk, Metode Dakwah, Edisi Revisi (Cet.Iii; Jakarta: Kencana, 2009), h. 3.

${ }^{14}$ A. Ilyas Ismail Dan Prio Hotman, Filsafat Dakwah: Rekayasa Membangun Agama Dan Peradaban Islam (Cet.1, Jakarta: Kencana, 2011), h. 77.

${ }^{15}$ Acep Aripudin, Pengembangan Metode Dakwah: Respons Dai Terhadap Dinamika Kehidupan Beragama Masyarakat Di Kaki Bukit Ciremai, h. 5.
} 
orang dalam konteks khusus. ${ }^{16}$ Di samping itu, kepribadian yang baik yakni kepribadian yang bersifat rohani (psikologis) dan kepribadian yang bersifat fisik juga mutlak dimiliki sebagai salah satu faktor keberhasilan dakwah. ${ }^{17}$.

Peranan dai atau mubalig sangat penting dalam proses dakwah, karena dai atau mubalig yang akan melaksanakan berbagai langkah strategis seperti merencanakan pesan, menetapkan metode, memilih media sesuai dengan kondisi mad'u. ${ }^{18}$ Berbagai peran sentral yang menjadi tanggung jawab dai dalam aktivitas dakwah mengisyaratkan perlunya seorang dai selalu memperbaiki kualitas diri baik ilmu maupun amalannya. Karena persyaratan utama seorang dai ideal adalah berilmu dan beramal, berteori dan mempraktikkannya. ${ }^{19}$

Kualitas ilmu dan implementasinya menjadikan seorang dai lebih mudah berinteraksi dengan mad'u. Langkah strategis yang perlu diperhatikan oleh dai adalah ketika ingin menyampaikan materi (pesan), dai harus memahami terlebih dahulu pesan tersebut. ${ }^{20}$ Karena dengan memahami pesan yang akan disampaikan, dai akan lebih mudah untuk berdakwah baik dengan lisan maupun dengan cara pengaplikasian sehingga mad'u lebih mudah menerima dan menjalankan pesan dakwah yang diterima.

Pemahaman pesan dakwah sebelum disampaikan merupakan salah satu prinsip dakwah yang harus dipahami dan diamalkan oleh dai. Karena sesungguhnya, berdakwah harus dimulai dari diri sendiri (ibda binafsik), kemudian berusaha menjadikan dirinya dan keluarganya menjadi

\footnotetext{
${ }^{16}$ Menurut Toto Tasmara dikutip Moh. Ali Aziz, Ada Dua Macam Pendakwah Yakni Secara Umum Yaitu Setiap Muslim Yang Sudah Mukalaf (Sudah Dewasa) dan Secara Khusus Yaitu Muslim Yang Telah Mengambil Spesialisasi (Mutakhashish) Dibidang Agama Islam Seperti Ulama., Lihat Moh. Ali Aziz, Ilmu Dakwah Edisi Revisi, H. 216.

${ }^{17}$ Faizah \& Lalu Muchsin Effendi, Psikologi Dakwah (Cet: 2, Jakarta: Kencana, 2009) H. 89.

${ }^{18}$ Anwar arifin, h. 236.

${ }^{19}$ Moh. Ali Aziz, Ilmu Dakwah Edisi Revisi (Jakarta: Kencana, 2009), h. 221.

${ }^{20}$ Moh. Ali Aziz, Ilmu Dakwah Edisi Revisi (Jakarta: Kencana, 2009), H. 221.
} 
contoh atau teladan bagi masyarakat. ${ }^{21}$ Pengamalan prinsip dakwah tersebut berdampak pada terwujudnya efektivitas dakwah.

\section{Urgensi Keteladanan dalam Proses Dakwah}

Dakwah pada masa kini semakin berkembang pesat. Aktivitas dakwah sebagai proses penyampaian nilai Islam dilakukan dengan ragam kegiatan di antaranya melalui tulisan, lisan dan tindakan nyata. Metode yang dilakukan juga beragam seperti menasihati, memerintahkan hal yang baik dan melarang hal yang buruk, khotbah, tabligh, keteladanan dan ragam metode lainnya. $^{22}$

Menganalisis ragam metode yang disebutkan, keteladanan merupakan suatu metode yang tidak asing lagi didengar. Metode yang senantiasa dirindukan dan dipertanyakan oleh umat. Di tengah hiruk pikuk modernisasi dan dalam perkembangan modernisme, kekuatan iman semakin mengalami degradasi, akhirnya timbul kehampaan spiritual yang melanda umat Islam. ${ }^{23}$

Keteladanan merupakan salah satu metode dakwah yang dikenal dengan sebutan dakwah bi al-khal atau dakwah dengan tindakan yakni suatu aktivitas dakwah dengan mencontohkan pesan dakwah kepada mad'u. Keteladanan berasal dari kata teladan yang berarti sesuatu yang patut dicontoh, dari kata teladan ditambah dengan imbuhan "ke" dan akhiran "an" menjadi keteladanan yaitu hal yang dapat ditiru atau dicontoh. ${ }^{24}$

Keteladanan bersumber dari usaha keras dan gigih untuk membangun kredibilitas diri dan kepercayaan publik, mengajak diri agar senantiasa berbuat baik, melakukan makruf dan mencegah kemungkaran serta menguasai bidang agama. Keteladanan bagi seorang dai sangat

\footnotetext{
${ }^{21}$ Faizah dan Lalu Muchsin Effendi, Psikologi Dakwah ( Cet. Ii; Jakarta: Kencana, 2009) h. xii.

${ }^{22}$ Moh. Ali Aziz, IImu Dakwah Edisi Revisi (Jakarta: Kencana, 2009), h. 226.

${ }^{23}$ M. Munir Dkk, Metode Dakwah, Edisi Revisi (Cet.Iii; Jakarta: Kencana, 2009), h. 4.

${ }^{24}$ Departemen Pendidikan Nasional, Kamus Besar Bahasa Indonesia (Cet. III; Jakarta: Balai Pustaka,
} 2005), h. 1160 . 
penting karena merupakan langkah strategis dalam membina kepercayaan mad'u untuk mewujudkan efektivitas dakwah ke arah terciptanya kehidupan yang Islami. ${ }^{25}$

Tugas dan tanggung jawab merubah umat kepada kehidupan yang sesuai dengan hukum Tuhan tidaklah mudah. Dai baik sebagai sebagai sentral dakwah yang berkewajiban menyampaikan risalah Islam terkadang melakukan kekeliruan dalam aktivitas dan perjalanan dakwahnya. Kekeliruan yang dilakukan oknum dakwah seperti saling menjelekkan dan merendahkan, tergesa-gesa dalam langkah, tidak melakukan syura ketika mengambil keputusan strategis, reaksioner, jatuh dalam perangkap musuh serta beberapa kekeliruan lainnya yang berdampak serius pada kepercayaan masyarakat terhadap Islam. ${ }^{26}$

Seorang dai yang mengalami degradasi moral dan nilai, pesan dakwahnya akan diacuhkan. Kata dan perbuatannya tidak akan berpengaruh kepada masyarakat yang didakwahi. Sehingga efektivitas dakwah tidak akan terwujud. Ragam penyakit yang banyak melanda dai di antaranya yaitu bakhil yang diperturutkan, mengikuti hawa nafsu dan takjub dengan pendapat pribadinya. $^{27}$

Berbagai kekeliruan dan ragam penyakit yang sering melanda dai, mengisyaratkan perlunya kontrol diri pada diri seorang dai. Kontrol diri yang baik berimplikasi pada pertumbuhan dan perkembangan kepribadian yang lebih baik dan posistif pada dai. Sehingga lebih memudahkan dalam proses dakwah. Kepribadian yang baik sangat penting karena pada hakikatnya berdakwah tidak hanya menyampaikan teori, tetapi juga memberikan teladan bagi umat yang diseru. Imam Shadiq as mengatakan” Seorang alim yang tidak mengamalkan ilmunya,

\footnotetext{
${ }^{25}$ Anwar Arifin, Dakwah Kontemporer Sebuah Studi Komunikasi (Cet. I; Yogyakarta: Graha Ilmu, 2011), h. 238 .

${ }^{26}$ Wahyu Ilaihi dan Harjani Hefni Polah, Pengantar Sejarah Dakwah (Cet.Ii; Jakarta: Kencana, 2012), h. 237.

${ }^{27}$ Wahyu Ilaihi dan Harjani Hefni Polah, Pengantar Sejarah Dakwah (Cet.II; Jakarta: Kencana, 2012), h. 237.
} 
maka nasihatnya akan cepat menguap, laksana lenyapnya air hujan dari batu yang licin." ${ }^{28}$ Hal itu menandakan pentingnya seorang dai mengamalkan ilmu yang dimilikinya.

Dai sebagai panutan seyogyanya memahami bahwa setiap aspek kehidupannya menjadi sorotan umat. Hal ini dikarenakan kedudukan dai di tengah masyarakat yang cukup penting ibarat seorang pemimpin. Posisi dai sebagai seorang pemuka masyarakat dengan sendirinya menjadikan segala aspek kehidupan dai baik perkataan maupun sikap dan tindakannya selalu dijadikan tolak ukur bagi masyarakat. Kejatuhan dai adalah kejatuhan agama, karena tegak dan berkembangnya Islam berada di tangan para dai. ${ }^{29}$

Tegak dan berkembangnya Islam sebagai isyarat efektivitas dakwah dibangun oleh dai atau mubaliq yang terpercaya karena berakhlak mulia, cakap, cerdas, terampil, visioner, dan berani serta memiliki keulamaan, ketokohan dan kepemimpinan. ${ }^{30}$ Ragam karakteristik yang melingkupi tersebut merupakan gambaran seorang dai yang ideal dan teladan di tengah umat.

Menganalisis peran sentral dai dengan keteladanannya menginsyaratkan pentingnya kehati-hatian seorang dai dalam tindak tanduknya. Sikap masa bodoh dan acuh terhadap pandangan umat akan dirinya dapat berakibat fatal pada ketidak efektifan dakwah yang dilakukannya bahkan menjadikan umat menjauh dari dakwah. Sebaliknya, akhlak mulia dan kepribadian yang baik akan menarik orang disekitarnya untuk datang dan berbondong bondong belajar kepadanya.

${ }^{28}$ Murtadha Husaini, Kode Etik Muballig Tuntunan Dakwah Secara Islam, Trj: Salman Fadhlullah ( Cet. 1,tt: Citra, 2011), h. 129

${ }^{29}$ Moh. Ali Aziz, Ilmu Dakwah, Edisi Revisi (Cet. II; Jakarta: Kencana, 2009), h. 231.

${ }^{30}$ Anwar Arifin, dakwah kontemporer, h. 236. 


\section{Konsep Efektivitas Dakwah}

Dakwah merupakan proses peningkatan iman dalam diri manusia sesuai syariat Islam. Peningkatan iman ini termanifestasi dalam peningkatan pemahaman, kesadaran, dan perbuatan. ${ }^{31}$ Peningkatan iman dapat terwujud dengan adanya seruan atau ajakan kepada keinsafan, serta adanya usaha untuk mengubah situasi kepada situasi yang lebih baik dan sempurna yang dilakukan terhadap pribadi maupun masyarakat. ${ }^{32}$

Terjadinya peningkatan iman yang termanifestasi dalam beberapa aspek pada diri mad'u menyiratkan tercapainya efektivitas dakwah. Karena dakwah merupakan suatu aktivitas yang menghendaki terjadinya perubahan pada diri individu atau kelompok yang menjadi sasaran dakwah. Adapun evaluasi efektivitas dakwah dapat dianalisis melalui parameter perubahan yang terjadi dengan ciri-ciri sebagai berikut:

a. Timbul pengertian (pemahaman) pada diri mad'u

b. Mad'u merasa terhibur oleh dakwah yang diterima

c. Tercipta atau meningkatnya hubungan baik antara dai dengan mad'u

d. Terjadi perubahan sikap mad'u sebagai efek dari dakwah yang diterima

e. Dakwah berhasil memancing respon mad'u berupa tindakan sesuai dengan pesan dakwah yang diterima. ${ }^{33}$

Menganalisis ciri-ciri yang telah dipaparkan, menunjukkan bahwa parameter efektivitas dakwah terletak pada perubahan pola pikir, sikap dan tindakan ke arah yang lebih baik yang diharapkan mengantarkan pelakunya mampu menikmati kebahagiaan dunia akhirat.

${ }^{31}$ Moh. Ali Aziz, Ilmu Dakwah, Edisi Revisi (Cet. II; Jakarta: Kencana, 2009), H. 19-20.

${ }^{32}$ M. Quraish Shihab, Membumikan Al-Quran; Fungsi dan Peran Wahyu dalam Kehidupan Masyarakat (Bandung: Mizan, 1994), h. 194.

${ }^{33}$ Faizah dan Lalu Muchsin Effendi, Psikologi Dakwah ( Cet. II; Jakarta: Kencana, 2009) h. xv. 


\section{Dakwah kontemporer}

Memasuki masa reformasi, kehidupan dakwah mendapatkan angin segar ditandai dengan peluang aktivitas keagamaan masyarakat muslim yang lebih terbuka lebar. ${ }^{34}$ Hal ini menandakan bahwa dakwah dari masa ke masa mengalami perkembangan yang cukup dinamis, Berbagai organisasi dan partai politik Islam juga semakin menandai perkembangan dakwah.

Perkembangan dakwah yang semakin pesat juga ditandai dengan ragam bentuk dakwah seperti tabligh, taklim, ceramah, atau dalam bentuk semangat pemahaman Islam, baik dalam skala pribadi maupun publik baik di daerah pedesaan maupun di perkotaan. Menjamurnya aktivitas dakwah tersebut menggambarkan dinamika dakwah di era kontemporer.

Dakwah kontemporer dengan bentuknya yang sangat beragam, baik yang bersifat personal dan dakwah jamaah juga terbagi atas beberapa bagian. Di samping itu, sektor dakwah juga terbagi dan digeluti sesuai profesi atau minat dan kompetensi masing-masing dai, sehingga sistem dan metode dakwah yang dilakukan juga beragam. ${ }^{35}$

Keragaman bentuk dakwah memberikan dampak positif dalam aktivitas dakwah, namun di dalam tubuh jamaah dakwah terdapat kelemahan mendasar meskipun tidak diserang oleh pihak lain, di antaranya adalah kelemahan sistem dakwah, kesalahan metode dan kelemahan dalam sarana. ${ }^{36}$

Ditemukannya beberapa problematika dan tantangan dakwah kontemporer menimbulkan keprihatinan. Hal ini diperparah dengan keharusan menghadapi tantangan dari arus komunikasi

\footnotetext{
${ }^{34}$ Wahyu Ilaihi dan Harjani Hefni Polah, Pengantar Sejarah Dakwah (Cet.II; Jakarta: Kencana, 2012), h. 200.

${ }^{35}$ Wahyu Ilaihi dan Harjani Hefni Polah, Pengantar Sejarah Dakwah (Cet.II; Jakarta: Kencana, 2012), h. 236.

${ }^{36}$ Wahyu Ilaihi dan Harjani Hefni Polah, Pengantar Sejarah Dakwah (Cet.II; Jakarta: Kencana, 2012), h. 238
} 
media massa berupa banyaknya informasi atau pesan media massa yang tidak sejalan dengan dakwah seperti tayangan kekerasan, pornografi dan pornoaksi. ${ }^{37}$

Tantangan dakwah yang juga bersumber dari aspek budaya global yang perlahan tetapi pasti telah mengikis moral umat adalah ajang pencarian bibit berbakat dengan system pengkarantinaan peserta laki-laki dan perempuan dalam satu rumah. Pengaburan batas norma dengan tinggal serumah yang bukan muhrim dengan alasan jalinan keakraban dan persahabatan merupakan fenomena kecil yang ditawarkan kaum kapitalis untuk menggiring masyarakat menuju kehidupan liberal, materialisme dan hedonisme. ${ }^{38}$

Problematika dakwah tersebut membutuhkan pembenahan dalam berbagai aspek yang melingkupi aktivitas dan proses dakwah yang diharapkan mampu menjadikan aktivitas dakwah menjadi lebih baik, efektif dan efisien. Karena dakwah merupakan suatu aktivitas yang bertujuan untuk menciptakan perubahan pada diri objek dakwah yakni suatu upaya memindahkan umat dari satu situasi ke situasi lainnya, dari situasi negatif ke situasi positif, dari kekufuran menjadi beriman, dan dari kemaksiatan kepada ketaatan kepada hukum Tuhan untuk mencapai keridaan Allah swt. ${ }^{39}$ Perubahan yang terjadi sebagai perwujudan efektivitas dakwah akan menciptakan harmoni kehidupan di era kontemporer sehingga kebahagiaan hidup dapat dirasakan dengan lenyap atau berkurangnya penyakit modernisasi yang melanda.

\section{Dakwah melalui Implementasi keteladanan Dai}

Maraknya aktivitas dakwah kontemporer baik yang bisa terlihat langsung maupun terpantau melalui media televisi atau media massa lainnya menggambarakan perkembangan dakwah yang cukup menggembirakan.

37 Anwar Arifin, Dakwah Kontemporer Sebuah Strudi Komunikasi (Cet. I; Yogyakarta: Graha Ilmu, 2011), h. 225 .

${ }^{38}$ Wahyu Ilaihi dan Harjani Hefni Polah, Pengantar Sejarah Dakwah (Cet.II; Jakarta: Kencana, 2012), h. 204.

${ }^{39}$ Malik Idris, Strategi Dakwah Kontemporer(Cet. 1; Makassar: Sarwah Press, 2007), h. 12. 
Menjamurnya majelis taklim dan berbagai bentuk kajian Islam lainnya yang merupakan bagian dari bentuk dakwah menandakan girah umat akan dakwah cukup tinggi. Namun, di tengah hiruk pikuknya dakwah, krisis moral juga tidak kurang lajunya dengan pertumbuhan dan perkembangan dakwah.

Mewujudkan tujuan dakwah di era kontemporer dalam realitas umat yang sudah terkontaminasi dengan budaya global dan pola hidup permissif tidak mudah. Daya kritis dan analitis masyarakat semakin tajam. Segala aspek kehidupan dai menjadi sorotan. Sikap apatis banyak ditemui dikalangan masyarakat terhadap tindak tanduk mereka yang dianggap tinggi pemahaman agamanya. Sikap apatis umat berimplikasi pada pengamalan pesan dakwah yang diterima.

Penerimaan mad'u terhadap pesan dakwah bila dianalisis, dipengaruhi oleh karakteristik dai penyampai pesan dakwah tersebut. Pengabaian mad'u terhadap pesan dakwah seringkali bersumber dari penilaian subjektif mad'u terhadap dai dan kehidupannya. Hal ini terutama di kalangan masyarakat awam dan pertengahan yang menjadikan mereka bersikap apatis terhadap dakwah.

Kritik pedas dan cemoohan tidak sungkan dikatakan, bahkan suatu kesalahan yang dilakukan tidak segan-segan didalihkan kepada yang dianggap memberikan contoh. Hal ini mengisyaratkan bahwa kebenaran yang dilakukan oleh dai atau mereka yang sejajar dengan dai lambat laun akan diikuti (menjadi inspirasi). Adapun kesalahan atau kekeliruan yang terjadi akan dicemooh dan dijadikan argumen penyerang pembenaran sikap mereka yang menentang pesan dakwah yang diterima. Hal akan berdampak jauhnya mad'u dari dakwah Islam.

Sorotan masyarakat terhadap dai meliputi seluruh aspek kehidupannya baik dalam ucapan, sikap dan perbuatannya. Bahkan keluarga dai pun tidak luput dari sasaran pengamatan masyarakat. Anggapan masyarakat yang sangat tinggi terhadap dai terkadang mengesampingkan 
kemanusiawian kehidupan dai. Tuntutan untuk menjadi pribadi yang sempurna merupakan tantangan yang tidak mudah.

Dai dalam pandangan masyarakat selayaknya adalah pemimpin yang harus jadi panutan (teladan). Karena itu, seorang dai yang bijaksana perlu senantiasa berhati-hati dalam sikap, ucapan dan perbuatannya. Penting bagi seorang dai untuk selalu mengontrol dan memperhatikan ucapan, sikap dan perbuatannya, karena dai merupakan pendidik bagi orang lain dengan karakteristik yang dimilikinya.

Karakteristik dai yang menjadi teladan umat memberikan pengaruh yang tidak sedikit terhadap mad'u baik mad'u yang masih awam, mad'u yang apatis dan mad'u religius. Keteladanan yang ditampakkan oleh dai mampu menginspirasi dan memotivasi orang lain baik sengaja ataupun tidak agar mau mempelajari ajaran agama dan mengamalkannya.

Keteladanan dai merupakan suatu inspirasi bagi mad'u untuk melakukan hal yang sama sebagai suatu bentuk imitasi pelaksanaan ajaran agama yang dengan sendirinya menjadi suatu kebiasaan yang baik. Hal ini mengisyaratkan bahwa, efektivitas dakwah melalui keteladanan meskipun memerlukan perjuangan yang tidak mudah, namun dampak yang ditimbulkannya merupakan hal yang luar biasa. Perubahan yang positif bagi mad'u menuju pengaplikasian hukum Tuhan dalam realitas kehidupan baik pribadi, keluarga dan masyarakat akan menjadikan tatanan kehidupan yang aman dan tentram sehingga mampu mencapai dan mewujudkan kebahagiaan dunia akhirat. 


\section{PENUTUP}

a. Dai (subjek dakwah) adalah setiap orang yang mengajak kepada perubahan yang lebih baik dalam menjalankan nilai Islam baik berupa individual, kelompok, organisasi, atau lembaga yang dipanggil untuk melakukan tindakan dakwah. Tanggung jawab dakwah yang tidak mudah mengisyaratkan seorang dai harus memiliki beberapa kompetensi yang meliputi kekuatan intelektual (knowledge), keterampilan (skill), sikap dan moral (attitude), serta kekuatan spiritual (spiritual power).

b. Keteladanan merupakan salah satu metode dakwah yang dikenal dengan sebutan dakwah $b i$ al-khal atau dakwah dengan tindakan yakni suatu aktivitas dakwah dengan mencontohkan pesan dakwah kepada mad'u.

c. Efektivitas dakwah adalah terwujud atau tercapainya tujuan dilakukannya dakwah yakni terjadinya perubahan pola pikir, sikap dan tindakan ke arah yang lebih baik sehingga mengantarkan pelakunya menikmati kebahagiaan dunia akhirat.

d. Dakwah kontemporer (masa kini/masa reformasi) berkembang cukup pesat di tandai dengan peluang aktivitas keagamaan masyarakat muslim yang lebih terbuka lebar. Munculnya organisasi dan partai politik Islam, serta maraknya ragam bentuk dakwah seperti tabligh, taklim, ceramah, atau dalam bentuk semangat pemahaman Islam, baik dalam skala pribadi maupun publik baik di daerah pedesaan maupun di perkotaan.

e. Karakteristik dai yang menjadi teladan umat memberikan pengaruh yang tidak sedikit terhadap mad'u baik mad'u yang masih awam, mad'u yang apatis dan mad'u religius. Keteladanan yang ditampakkan oleh dai mampu menginspirasi dan memotivasi orang lain baik sengaja ataupun tidak agar mau mempelajari ajaran agama dan mengamalkannya. Keteladanan dai merupakan suatu inspirasi bagi mad'u untuk melakukan hal yang sama sebagai suatu bentuk imitasi pelaksanaan ajaran agama yang dengan sendirinya menjadi suatu kebiasaan yang baik. 


\section{DAFTAR PUSTAKA}

Arifuddin, Metode Dakwah Dalam Masyarakat Plural; Suatu Penelitian Kualitatif, Jakarta: Rabbani Press, 2012.

Arifin, Anwar. Dakwah Kontemporer Sebuah Strudi Komunikasi, Cet. I; Yogyakarta: Graha Ilmu, 2011.

Aripuddin, Acep. Pengembangan Metode Dakwah; Respons Dai Terhadap Dinamika Kehidupan Beragama di Kaki Ciremai, Ed.1, Jakarta: Rajawali Pers, 2011.

Abidin Ass, Djamalui. Komunikasi dan Bahasa Dakwah, Jakarta: Gema Insani Press, 1996.

Aziz, Moh. Ali. Ilmu Dakwah Edisi Revisi, Jakarta: Kencana, 2009.

Departemen Pendidikan Nasional, Kamus Besar Bahasa Indonesia, Cet. III; Jakarta: Balai Pustaka, 2005.

Faizah dan Lalu Muchsin Effendi, Psikologi Dakwah, Cet. II; Jakarta: Kencana, 2009.

Husaini, Murtadha, Kode Etik Muballig Tuntunan Dakwah Secara Islam, Trj: Salman Fadhlullah, Cet. 1,tt: Citra, 2011.

I@sa Bin S $\{@$ urah Attirmidz\I,'Abu 'I@sa Muh\}ammad Bin >. S\{unan Al-Turmudz>I>, Juz.IV , Semarang: Toha Putra, Tt.

Ilaihi, Wahyu dan Harjani Hefni Polah, Pengantar Sejarah Dakwah, Cet.II; Jakarta: Kencana, 2012.

Ismail, A. Ilyas dan Prio Hotman, Filsafat Dakwah: Rekayasa Membangun Agama dan Peradaban Islam, Cet.1, Jakarta: Kencana, 2011.

Idris, Malik. Strategi Dakwah Kontemporer, Cet. 1; Makassar: Sarwah Press, $2007 .$.

Jumantoro, Totok. Psikologi Dakwah dengan Aspek-Aspek Kejiwaan yang Qur'ani, Cet.1; Amzah, 2001.

Muhyiddin, Asep dan Agus Ahmad Safei, Metode Pengembangan Dakwah, Cet.I; Bandung: Pustaka Setia, 2002.

M. Munir dkk, Metode Dakwah, Edisi Revisi, Cet.III; Jakarta: Kencana, 2009.

Shihab, M. Quraish. Membumikan Al-Quran; Fungsi dan Peran Wahyu dalam Kehidupan Masyarakat, Bandung: Mizan, 1994. 